\title{
ANALISIS PERKEMBANGAN WILAYAH PROVINSI JAWA BARAT UNTUK ARAHAN PEMBANGUNAN BERBASIS WILAYAH PENGEMBANGAN
}

\author{
Dian Noviyanti ${ }^{1}$, Andrea Emma Pravitasari'2, Sahara Sahara ${ }^{3}$ \\ 1Departemen Ilmu Tanah dan Sumberdaya Lahan Faperta, IPB \\ Jln. Meranti, Kampus IPB Darmaga Bogor 16680, Jawa Barat, Indonesia \\ 2Departemen Ilmu Tanah dan Sumberdaya Lahan Faperta, IPB \\ Jln. Meranti, Kampus IPB Darmaga Bogor 16680, Jawa Barat, Indonesia \\ ${ }^{3}$ Departemen Ilmu Ekonomi FEM, Institut Pertanian Bogor \\ Jln. Kamper, Kampus IPB Darmaga Bogor 16680, Jawa Barat, Indonesia \\ e-mail: dian.noviyanti@bps.go.id
}

\begin{abstract}
Abstrak
Jawa Barat adalah wilayah dengan jumlah penduduk terbesar dan memiliki ketimpangan pembangunan level tinggi. Perekonomian masih didominasi wilayah yang dekat pusat pemerintahan. Upaya untuk menanggulangi ketidaksetaraan pembangunan adalah dengan pembangunan berkonsep dimensi kewilayahan. Terdapat enam wilayah pengembangan (WP) di Jawa Barat dengan karakteristik wilayah yang berbeda-beda baik dalam segi ekonomi, demografi serta sumberdaya alam. Faktor apa saja yang dominan serta pengaruhnya pada perkembangan wilayah masing-masing WP sangat penting untuk perumusan solusi pembangunan wilayah yang efektif. Penelitian ini bertujuan untuk mengetahui karakteristik dan pengelompokan wilayah, perkembangan perekonomian, tingkat perkembangan wilayah serta arahan rencana dan strategi pembangunan wilayah tiap WP. Metode yang digunakan yaitu analisis tipologi klassen, analisis gerombol, skalogram dan analisis deskriptif. Hasil penelitian menunjukkan tingkat perkembangan wilayah dan perekonomian masih didominasi WP Bodebekpunjur dan KK Cekungan Bandung. Strategi pembangunan yaitu dengan meningkatkan perkembangan wilayah daerah belakang (hinterland) pada tiap WP. Pusat-pusat pertumbuhan baru tersebut diharapkan dapat mendorong laju pertumbuhan ekonomi.
\end{abstract}

Kata kunci: perkembangan wilayah, pemerataan, ekonomi, WP, strategi pembangunan

\begin{abstract}
West Java is the region with the largest population and has a high level of development inequality. The economy is still dominated by areas near the center of government. The effort to overcome development inequality is through the development of the regional dimension concept. There are six development areas (WP) in West Java with different regional characteristics in terms of economy, demography and natural resources. What factors are dominant and their influence on the development of the regions of each WP is very important for the formulation of effective regional development solutions. This study aims to determine the characteristics and grouping of regions, economic development, the level of regional development and the direction of regional development plans and strategies for each WP. The method used is Klassen typology analysis, cluster analysis, scalogram and descriptive analysis. The results showed the level of regional and economic development was still dominated by WP Bodebekpunjur and KK Bandung Basin. The development strategy is to increase the development of the hinterland in each WP. The new growth centers are expected to drive the pace of economic growth.
\end{abstract}

Keywords: regional development, equity, economy, WP, development strategy 


\section{PENDAHULUAN}

Paradigma baru pembangunan menurut Rustiadi et al. (2009) harus diarahkan pada terjadinya pemerataan (equity), pertumbuhan (eficiency), dan keberlanjutan (sustainability). Pemerataan tidak menyiratkan pembangunan yang sama disemua daerah, melainkan pemanfaatan potensi masing-masing daerah sehingga bermanfaat bagi pertumbuhan ekonomi penduduk diseluruh wilayah (Priadi 2018). Setiap wilayah atau bagian dari wilayah secara spasial memiliki beragam potensi dan kondisi. Jawa Barat merupakan daerah dengan penduduk terbesar yang berjumlah 48.683 .700 pada tahun 2018 (18.37\% penduduk Indonesia). Kondisi aktual saat ini, aktivitas perekonomian Jawa Barat didominasi daerah dekat Jakarta dan Bandung dengan share 60\% PDRB Jawa Barat (BPS 2017).

Penelitian Aprianoor dan Muktiali (2015) menyebutkan angka PDRB yang tinggi hanya didominasi oleh beberapa kota/kabupaten di Jawa Barat (Bekasi, Kota Bandung, dan Bogor), sedangkan kota/kabupaten lainnya hanya dapat menghasilkan sedikit pendapatan bahkan tidak sampai $50 \%$ dari pendapatan tiga wilayah tersebut. Pemusatan sumberdaya dan investasi di beberapa wilayah menurut Akrofi et al. (2018) dapat menyebabkan polarisasi dan ketidaksetaraan spasial. Ketimpangan Jawa Barat menurut penelitian Aprianoor dan Muktiali (2015) relatif tinggi dengan nilai Indeks Williamson 0,61. Strategi untuk mengatasi kesenjangan di Jawa Barat yaitu dengan menerapkan pembangunan berdimensi kewilayahan.

Pembangunan wilayah dapat memberikan gambaran sejauh mana suatu wilayah mempunyai peluang untuk berkembang (Latuconsina, 2017). Berdasarkan dokumen RPJMD tahun 20182023 dan RTRW tahun 2009-2029 yang tertuang dalam (Peraturan Gubernur Jawa Barat 2010), terdapat enam Wilayah Pengembangan (WP) yaitu:

1. WP Bodebekpunjur, terdiri dari wilayah Bogor, Bekasi, Kota Bekasi, Kota Depok,
Kota Bogor dan sebagian Cianjur (Kecamatan Cugenang, Kecamatan Pacet, Kecamatan Sukaresmi dan Kecamatan Cipanas). Sektor pariwisata, industri manufaktur, perikanan, perdagangan, jasa, pertambangan, agribisnis dan agrowisata merupakan sektor yang potensial untuk dikembangkan.

2. WP Purwasuka, mencakup daerah Subang, Purwakarta dan Karawang. Sektor pertanian, perkebunan, kehutanan, peternakan, perikanan, bisnis kelautan, industri pengolahan, pariwisata, dan pertambangan adalah sektor unggulan yang dikembangkan pada WP ini.

3. WP Ciayumajakuning, beranggotakan Kuningan, Cirebon, Majalengka, Indramayu, Sumedang dan Kota Cirebon. WP ini memiliki sektor potensial untuk dikembangkan yaitu sektor agribisnis, agroindustri, perikanan, pertambangan, dan pariwisata.

4. WP Priatim-Pangandaran, meliputi wilayah Garut, Tasikmalaya, Ciamis, Kota Tasikmalaya, Kota Banjar dan Pangandaran. Sektor pertanian, perkebunan, perikanan tangkap, pariwisata, industri pengolahan, dan pertambangan mineral merupakan sektor andalan untuk dikembangkan.

5. WP Sukabumi dan sekitarnya, mempunyai anggota Sukabumi, Kota Sukabumi dan Cianjur. Sektor potensial yang dikembangkan yaitu sektor pertanian, perkebunan, peternakan, perikanan tangkap, pariwisata, industri pengolahan, bisnis kelautan, dan pertambangan mineral.

6. WP Kawasan Khusus Cekungan Bandung, meliputi daerah Bandung, Bandung Barat, Kota Cimahi, Kota Bandung dan sebagian Sumedang (Kecamatan Jatinangor, Kecamatan Tanjungsari, Kecamatan Cimanggung, Kecamatan Sukasari dan Kecamatan Pamulihan). Pengembangan sektor potensial meliputi sektor pertanian 
hortikultura, industri non-polutif, industri kreatif, perdagangan dan jasa, pariwisata, dan perkebunan.

Pembangunan yang berdimensi kewilayahan dapat diwujudkan melalui optimalisasi potensi kewilayahan. Hal ini menjadi suatu keharusan dan menarik untuk dianalisis. Fakta yang melatar belakangi yaitu WP Bodebekpunjur dan KK Cekungan Bandung mendominasi kegiatan ekonomi Jawa Barat dengan share mencapai $60 \%$ PDRB Jawa Barat. WP lain juga memiliki potensi ekonomi dari sisi keberlanjutan pertumbuhan ekonominya. Pertumbuhan ekonomi WP lain di luar Bodebekpunjur dan KK Cekungan Bandung ternyata memiliki capaian yang cukup menggembirakan dan potensial. Penggalian potensi ekonomi sangat penting untuk dilakukan sebagai bagian dari konsep pembangunan kewilayahan. Hal tersebut bertujuan agar konvergensi ekonomi dapat dicapai terutama dengan mendorong transformasi dan akselerasi (BPS 2017).

Tiap WP memiliki karakteristik wilayah yang berbeda-beda baik dalam segi ekonomi, demografi serta sumberdaya alam. PDRB per kapita yang cukup tinggi tidak terjadi di seluruh Jawa Barat. Jumlah penduduk tidak merata diseluruh wilayah Jawa Barat, masih ada beberapa wilayah yang mendominasi wilayah lainnya. Hal ini merupakan salah satu indikasi perkembangan wilayah yang tidak merata dan pembangunan hanya terkonsentrasi pada titik lokasi tertentu saja.

Indikator lain yang digunakan untuk melihat perkembangan wilayah adalah infrastruktur fisik, misal jalan. Ketersediaan jalan antar wilayah Jawa Barat masih belum merata. Perbedaan terlihat antara kabupaten/kota di sekitar ibukota provinsi dan ibukota negara dengan Jawa Barat bagian selatan. Berdasarkan olahan data BPS dalam publikasi Jawa Barat dalam Angka 2018 terdapat perbedaan rasio panjang jalan terhadap luas wilayah di tiap WP. Hanya ada tiga WP yang rasionya di atas capaian Provinsi Jawa Barat (0.65) yaitu WP Bodebekpunjur (1.14) Purwasuka (0.76) dan
KK Cekungan Bandung (0.89). Sedangkan tiga WP sisanya yang berada di bagian selatan Jawa Barat yaitu WP PriatimPangandaran (0.57), Sukabumi dan sekitarnya (0.33) dan Ciayumajakuning (0.57) memiliki rasio di bawah rasio panjang jalan provinsi. Ketidakmerataan pembangunan infrastruktur ini menjadi permasalahan lain dalam pembangunan ekonomi kewilayahan.

Pertumbuhan industri di suatu wilayah baik industri kecil dan mikro maupun industri sedang dan besar juga merupakan indikator perkembangan wilayah. Menurut Tirado et al. (2016) pertumbuhan ekonomi modern ditandai dengan pemusatan aktivitas industri di lokasi tertentu yang mengakibatkan ketimpangan PDRB perkapita antar wilayah. Berdasarkan olahan data Analisis Sensus Ekonomi 2016 Hasil Listing Potensi Ekonomi Jawa Barat publikasi BPS terdapat persebaran industri yang tidak merata di tiap WP. Wilayah Pengembangan yang mempunyai persentase jumlah industri di bawah rata-rata Jawa Barat $(16,67 \%)$ yaitu WP Purwasuka (10,59\%) PriatimPangandaran $(16,49)$ serta Sukabumi dan sekitarnya (11,99\%). Sedangkan tiga WP sisanya yaitu Bodebekpunjur (22,91), Ciayumajakuning $(18,24)$, dan KK Cekungan Bandung $(19,78)$ mempunyai persentase jumlah industri di atas rata-rata provinsi.

Banyak faktor yang memengaruhi pembangunan wilayah Provinsi Jawa Barat. Identifikasi faktor dominan yang berpengaruh terhadap pembangunan wilayah masing-masing WP masih jarang dilakukan. Faktor apa saja yang dominan serta pengaruhnya pada perkembangan wilayah masing-masing WP sangat penting untuk perumusan solusi pembangunan wilayah yang efektif.

Setiap WP memiliki potensi, fokus pengembangan dan masalah yang berbedabeda. Keragaman dinamika internal masing-masing WP membutuhkan rencana dan strategi pembangunan yang tepat. Rencana harus didasarkan pada masalah, 
dasar kebutuhan, dan aset potensial daerah sehingga pengembangan dapat efisien dan efektif (Fafurida 2012). Perlunya mengetahui karakteristik setiap WP meliputi aspek kependudukan, sosial, sarana dan prasarana akan mempermudah dalam menyusun strategi pengembangan wilayah. Penelitian ini bertujuan untuk (1) menganalisis karakteristik wilayah dan potensi perkembangan perekonomian tiap WP (2) menganalisis tingkat perkembangan wilayah tiap WP dan 3) merumuskan arahan rencana dan strategi pembangunan wilayah untuk setiap WP di Provinsi Jawa Barat.

Ruang lingkup penelitian ini meliputi seluruh kabupaten/kota yang terbagi dalam 6 WP di Provinsi Jawa Barat. Kabupaten yang terbagi menjadi dua WP akan dianalisis pada WP dengan cakupan wilayah kecamatan terbesar. Kecamatan Cugenang, Pacet, Sukaresmi dan Cipanas yang masuk WP Bodebekpunjur dianalisis pada Kabupaten Cianjur (WP Sukabumi dan sekitarnya). Kecamatan Jatinangor, Tanjungsari, Cimanggung, Sukasari dan Pamulihan yang masuk WP KK Cekungan Bandung dianalisis pada Kabupaten Sumedang (WP Ciayumajakuning)

\section{METODE PENELITIAN}

Penelitian ini dilakukan di Provinsi Jawa Barat yang terdiri dari 6 wilayah pengembangan (WP) dan 27 Kabupaten/Kota pada Bulan MeiSeptember 2019. Penelitian ini menggunakan jenis data sekunder yang bersumber dari BPS dan Bappeda Provinsi Jawa Barat. Data tersebut meliputi data peta administrasi wilayah Jawa Barat, data tutupan lahan 2010, 2014, 2018, data PDRB ADHK 2010 menurut pengeluaran Tahun 2014-2017, data PODES 2018. Alat yang digunakan dalam penelitian ini adalah perangkat komputer yang dilengkapi dengan Microsoft Office, Software Geographic Information System (GIS), Software Statistica, Software R studio, dan alat tulis-menulis.

Karakteristik wilayah adalah sifat atau ciri khas suatu wilayah yang ditinjau dari berbagai aspek. Berdasarkan aspek fisik, karakteristik wilayah bisa dilihat dari luas lahan terbangun (built up area) dan luas lahan sawah. Pertumbuhan wilayah yang berkaitan dengan perubahan penggunaan lahan menjadi area perumahan, kawasan komersial atau industry menurut McGarigal et al. (2018) merupakan konversi lahan utama di dunia dan pada banyak kasus bersifat permanen. Penelitian ini menggunakan data atribut luas lahan terbangun peta landcover Jawa Barat tahun 2010, 2014 dan 2018. Selama kurun waktu delapan tahun bisa diketahui persentase perubahan lahan terbangun.

Tipologi Klassen menurut Muta'ali (2015) adalah model yang paling populer untuk mengidentifikasi tingkat perkembangan, pola dan struktur perekonomian wilayah. Tipologi ini menggunakan basis data besaran pendapatan Produk Regional Domestik Bruto (PDRB per kapita) dan laju pertumbuhan ekonomi (LPE) dengan pembagian berdasarkan rata-rata. LPE adalah indeks berantai dari masing-masing kegiatan ekonomi. Penelitian ini menggunakan lima titik tahun yaitu tahun 2014 sampai 2018 untuk mengetahui perkembangan perekonomian di wilayah Jawa Barat. Laju Pertumbuhan Ekonomi (LPE) dihitung mengggunakan rumus pada persamaan 1.

$\mathrm{LPE}=\frac{P D R B_{(n, b)}-P D R B_{(n-1, b)}}{P D R B_{(n-1, b, i)}} \times 100 \%$

Keterangan:

LPE : Laju Pertumbuhan Ekonomi

PDRB : Produk Domestik Regional Bruto

Menurut Sjafrizal (1997) tipologi klassen menghasilkan empat klasifikasi daerah yang masing-masing mempunyai karakteristik yang berbeda antara satu wilayah dengan wilayah lainnya. Untuk lebih jelasnya kuadran tipologi klassen tentang pertumbuhan di wilayah Jawa Barat dapat dilihat pada Tabel 1 berikut ini. 
Tabel 1 Kuadran tipologi Klassen

\begin{tabular}{cll}
\hline Laju & \multicolumn{2}{c}{ PDRB per kapita $(\mathrm{Y})$} \\
\cline { 2 - 3 } Pertumbuhan & $\mathrm{Y}_{\text {kabupaten/kota }}$ & $\mathrm{Y}_{\text {kabupaten/kota }}<$ \\
& $>\mathrm{Y}_{\text {Jawa Barat }}$ & \multicolumn{1}{c}{$\mathrm{Y}_{\text {Jawa Barat }}$} \\
\hline & Kuadran I: & Kuadran III: \\
& Wilayah & Wilayah \\
cepat maju & berkembang \\
$\mathrm{R}_{\text {kabupaten/kota }}>$ & dan cepat & cepat (high \\
$\mathrm{R}_{\text {Jawa Barat }}$ & tumbuh & growth but \\
& (high growth & low income) \\
& and & \\
& highincome) & \\
\hline & Kuadran II: & Kuadran IV: \\
& Wilayah & Wilayah \\
$\mathrm{R}_{\text {kabupaten/kota }}<$ & maju tapi & relatif \\
$\mathrm{R}_{\text {Jawa Barat }}$ & tertekan & tertinggal \\
& (low growth & (low growth \\
& but high & and low \\
& income) & income)
\end{tabular}

Sumber: Muta'ali (2015)

Pengelompokan

karakteristik wilayah berguna untuk menentukan tipologi wilayah berdasarkan karakteristik wilayah. Teknik analisis pengelompokan wilayah yaitu analisis gerombol (cluster analysis). Menurut Pribadi et al. (2017) analisis gerombol bertujuan untuk mengelompokkan obyek, sedemikian rupa sehingga obyek dalam satu kelompok memiliki karakteristik yang lebih mirip dibanding obyek dalam kelompok lain. Secara umum terdapat dua metode analisis gerombol yaitu metode berhirarki dan tidak berhirarki (Panuju dan Rustiadi 2013). Penelitian ini menggunakan delapan karakteristik wilayah sebagaimana terdapat pada bagian hasil dan pembahasan.

Analisis skalogram menurut Utari (2015) merupakan alat untuk mengidentifikasi pusat pertumbuhan wilayah berdasarkan fasilitas pelayanan yang dimilikinya, dengan demikian hierarki pusat - pusat pertumbuhan dan aktivitas pelayanan suatu wilayah dapat ditentukan. Rumus umum skalogram adalah seperti pada Persamaan 2.

Indeks Hirarki $(\mathrm{Ii})=\sum_{k}^{n}\left(F_{i k} \frac{n}{a k}\right)$

dimana:

$\frac{n}{a k}=$ bobot fasilitas penentu
Data yang digunakan meliputi data potensi desa (PODES) tahun 2011, 2014 dan 2018 yang dikeluarkan oleh BPS.

Menurut Fafurida (2012) informasi penting tentang perkembangan wilayah dibutuhkan untuk membuat perencanaan menjadi lebih mudah disusun. Analisis deskriptif merupakan salah satu teknik analisis untuk merumuskan arahan rencana dan strategi pembangunan wilayah. Hasil analisis ini dapat digunakan sebagai dasar dalam merumuskan pembangunan daerah. Analisis deskriptif ini pada dasarnya adalah pendeskripsian suatu proses yang mencakup upaya penelusuran dan pengungkapan informasi yang relevan terkandung dalam data. Tujuan analisis deskriptif menurut Pravitasari (2009) adalah memberikan gambaran dan interpretasi atas hasil analisis yang disajikan dalam bentuk grafis, dan gambar-gambar, serta menghitung ukuran-ukuran deskripsinya.

\section{HASIL DAN PEMBAHASAN Karakteristik Wilayah}

Karakteristik wilayah Jawa Barat berdasarkan aspek fisik dapat dilihat dari penggunaan lahan. Jawa Barat merupakan wilayah yang mempunyai sumberdaya alam beragam. Luas lahan tiap wilayah mengalami perkembangan penggunaannya. Perubahan luas lahan tiap tahun menunjukkan telah terjadi pergeseran struktur perekonomian. Berdasarkan data peta landcover Bappeda Jawa Barat Tahun 2010, 2014, dan 2018 dapat dianalisis pola penggunaan lahan dalam tiga tiik tahun tersebut.

Luas lahan terbangun merupakan salah satu faktor yang berpengaruh terhadap perkembangan wilayah dilihat dari aspek fisik. Tingginya jumlah penduduk dan aktivitas perekonomian di Jawa Barat membuat laju pertumbuhan lahan terbangun semakin meningkat tiap tahun. Daerah perkotaan dan area sekitarnya merupakan wilayah dengan lahan terbangun yang tinggi. Hal ini dipicu oleh perkembangan aktivitas ekonomi 
terutama sektor sekunder dan tersier yang pesat. Daya tarik perkotaan tersebut mendorong kepadatan penduduk yang disertai penambahan bangunan dengan fungsi perumahan dan fasilitas umum pendukungnya.

Menurut

Prawatya

(2013)

perkembangan lahan terbangun dipengaruhi oleh beberapa faktor antara lain historis, urbanisasi, jarak dengan kota besar, topografi, dan aksesibilitas. Persentase luas lahan terbangun yang mencirikan perkembangan wilayah Jawa Barat terdapat pada Gambar 1 dan 2. WP Bodebekpunjur merupakan wilayah yang mempunyai lahan terbangun tertinggi dengan persentase luas di atas 25\%. Posisi kedua diduduki oleh WP KK Cekungan Bandung dengan persentase luas di atas $17 \%$. Built up area terkecil berada pada WP Sukabumi dan sekitarnya (luas > $6 \%)$.

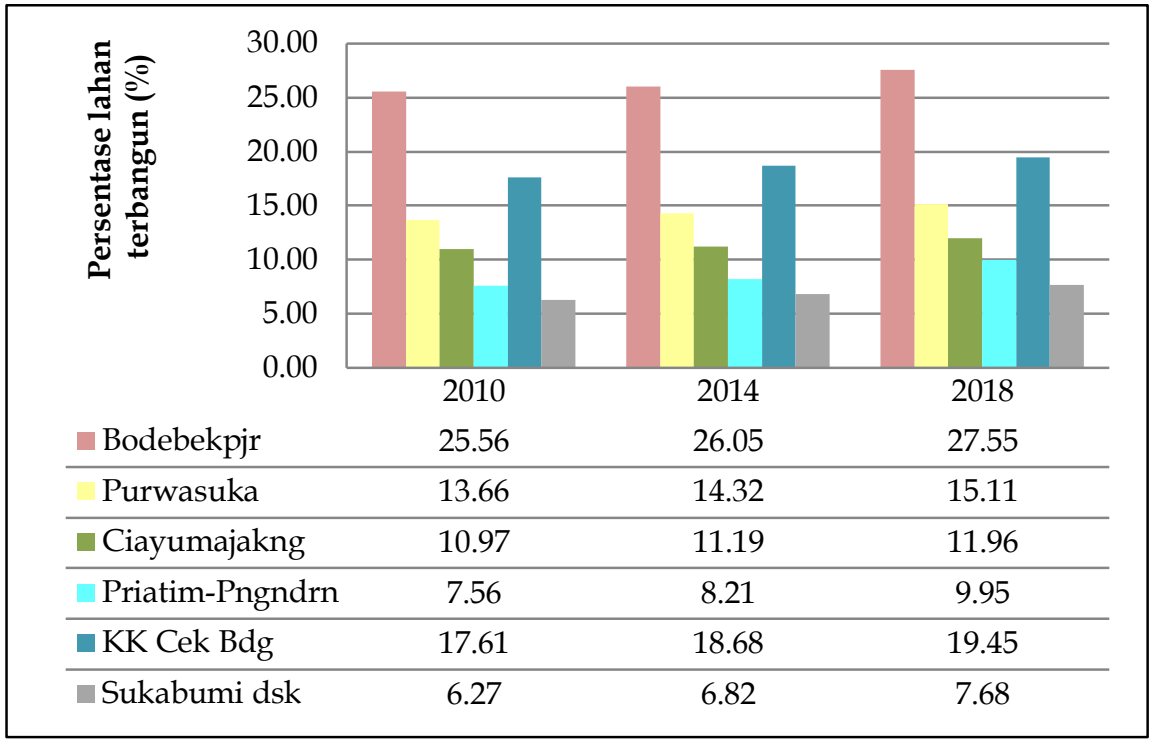

Gambar 1. Persentase lahan terbangun WP Jawa Barat tahun 2010, 2014 dan 2018

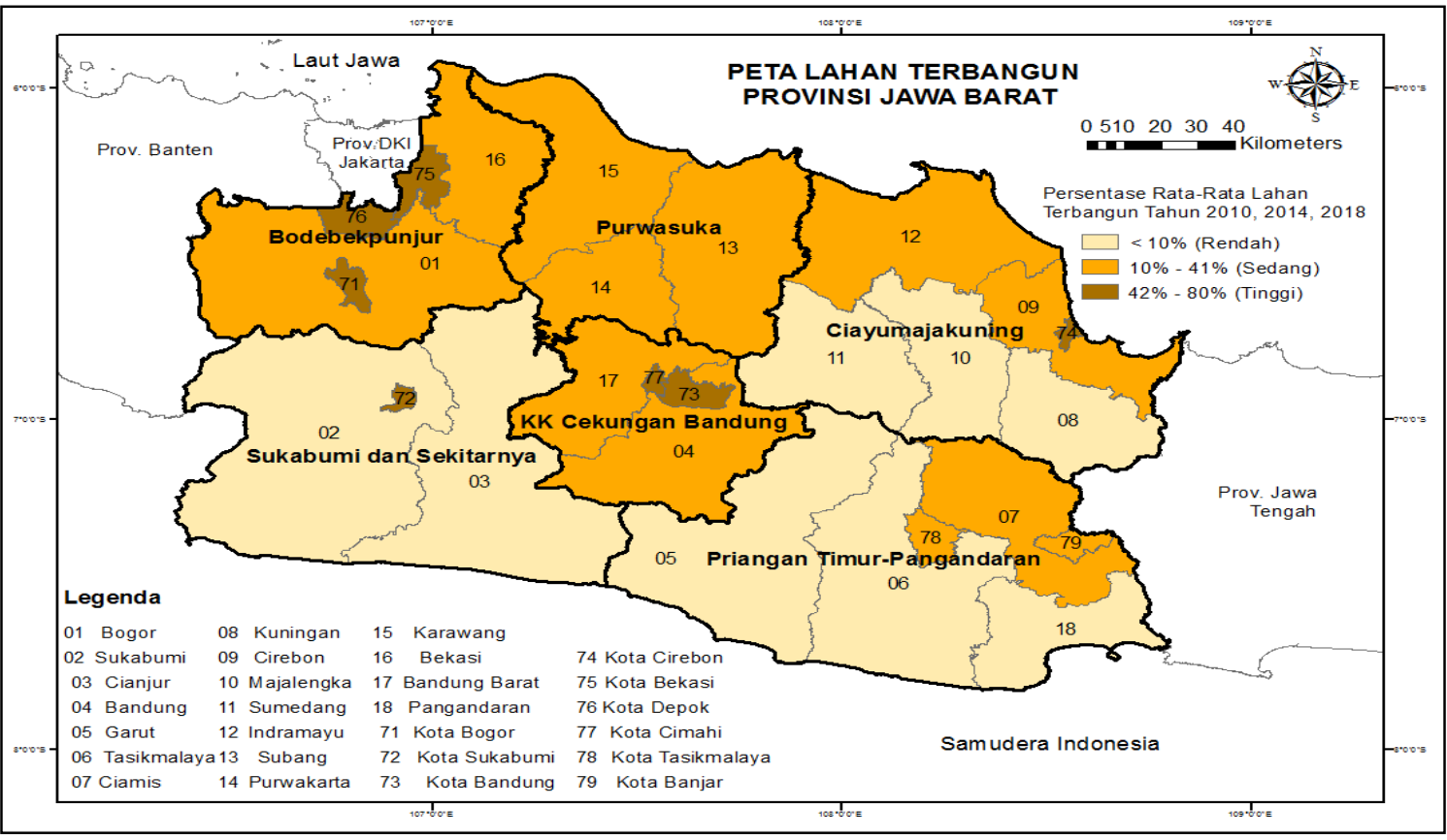

Gambar 2. Peta persentase rata-rata lahan terbangun WP Jawa Barat tahun 2011, 2014 dan 2018 
Perkembangan lahan terbangun yang cukup tinggi pada WP Bodebekpunjur dan KK Cekungan Bandung menunjukkan wilayah tersebut merupakan pusat kegiatan ekonomi dan pemerintahan. WP Sukabumi dan sekitarnya yang mempunyai area terbangun terkecil menandakan struktur perekonomian masih didominasi sektor primer dan belum banyak bergeser. Ratarata laju kenaikan lahan terbangun terbesar berada pada WP Priatim-Pangandaran dengan persentase $1.19 \%$. Hal ini berarti pada jangka waktu tahun 2010, 2014 dan 2018 WP tersebut mengalami kenaikan lahan terbangun rata-rata sebesar $1.19 \%$. Fenomena ini menunjukkan mulai begesernya struktur perekonomian pada WP Priatim-Pangandaran dari sektor primer ke sektor sekunder dan tersier.

Gambar 2 menunjukkan besarnya persentase lahan terbangun tiap kabupaten/kota dalam WP di Jawa Barat. Perkotaan merupakan wilayah dengan lahan terbangun yang cukup tinggi (> 10\%). Terdapat dua kota yang memiliki persentase lahan terbangun sedang dan tujuh kota dengan lahan terbangun tinggi. Hal ini menunjukkan kota sebagai daerah inti yang berperan sebagai pusat kegiatan. Wilayah sekitarnya sebagai daerah belakang (hinterland). Daerah inti memiliki aktivitas ekonomi tinggi yang ditandai dengan besarnya builtup area.

Wilayah dengan lahan terbangun tinggi sebagian besar terdapat pada WP Bodebekpunjur (3 kota), WP KK Cekungan
Bandung (2 kota) dan WP Ciayumajakuning (1 kota). Builtup area dengan kategori sedang dan rendah berada pada WP Purwasuka, Sukabumi dsk serta Priatim-Pangandaran. Kota Depok, Kota Bekasi, Kota Bogor, Kota Cimahi, Kota Bandung, Kota Cirebon memiliki persentase lahan terbangun tinggi (>42\%). Fakta tersebut didukung dengan tingkat kepadatan penduduk yang tinggi dan sangat tinggi. Pertambahan penduduk dengan luas wilayah tetap akan mendorong laju kenaikan lahan terbangun. Hal ini sesuai dengan penelitian dinamika perkembangan kota kecil oleh Baga (2015) yang menyatakan kepadatan penduduk berbanding lurus dengan luas lahan terbangun.

Peningkatan jumlah penduduk mengakibatkan kepadatan penduduk makin tinggi yang mempengaruhi peningkatan pembangunan. Hal ini menyebabkan perubahan pola penggunaan lahan, sehingga ruang terbangun semakin mendominasi dan mendesak ruang-ruang alami untuk berubah fungsi (Tulenan et al. 2014). Perubahan lahan pertanian menjadi area terbangun merupakan tanda adanya pergeseran sektor perekonomian dari sektor primer menjadi sektor sekunder dan tersier. Menurut Pratiwi dan Mutáali (2018) sektor maju dan cepat tumbuh didominasi oleh sektor perdagangan besar dan eceran, sektor transportasi serta pergudangan. Lahan pertanian sawah Jawa Barat menunjukkan wilayah mana yang masih bertumpu pada sektor primer dan mana yang sudah bergeser.

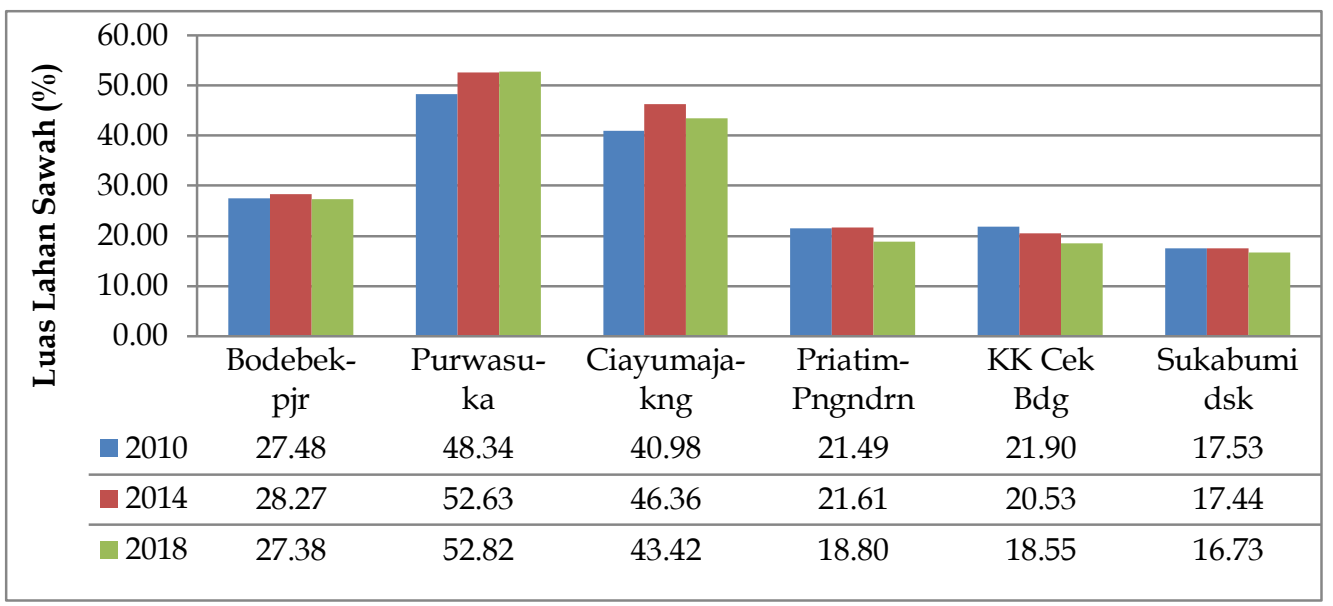

Gambar 3. Persentase luas lahan sawah WP Jawa Barat tahun 2010, 2014 dan 2018 
WP Purwasuka mempunyai luas sawah terbesar di Jawa Barat berdasarkan Gambar 3 dengan persentase luas yang terus meningkat. Luas lahan sawah terkecil terdapat pada WP Sukabumi dsk dengan persentase luas $16.73 \%$ pada tahun 2018. Pada WP Bodebekpunjur dan Ciayumajakuning luas lahan sawah berfluktuasi yaitu naik pada tahun 2014 dan turun pada tahun 2018. Luas sawah cenderung terus menurun pada WP Priatim-Pangandran, KK Cekungan Bandung serta Sukabumi dan sekitarnya. Hal ini disebabkan semakin terdesaknya area lahan sawah oleh lahan terbangun.

\section{Perkembangan Perekonomian dengan Tipologi Klassen}

Tipologi Klassen merupakan analisis yang digunakan untuk mengetahui pola dan struktur pertumbuhan ekonomi masingmasing daerah. Melalui analisis ini akan diketahui klasifikasi daerah berdasarkan dua Economic growth adalah indeks berantai dari masing-masing kegiatan ekonomi. Penelitian ini menggunakan lima titik tahun yaitu tahun 2014-2018 untuk mengetahui perkembangan perekonomian di Jawa Barat.

Kuadran tipologi klassen pada Gambar 4 menunjukkan perkembangan perekonomian di Jawa Barat dalam kurun lima tahun. Penentuan lokasi kuadran tersebut berdasarkan rata-rata laju pertumbuhan ekonomi (LPE) dan rata-rata PDRB per kapita Jawa Barat dengan nilai $5.36 \%$ dan Rp. $26,974,000,-$. Sebagian besar WP terdapat pada kuadran I yaitu wilayah cepat maju dan tumbuh dengan persentase $50 \%$ (3 WP). Kuadran III yaitu wilayah maju tapi tertekan beranggotakan WP Sukabumi dsk dan WP Priatim-pangandaran. WP Ciayumajakuning merupakan WP dengan kategori relatif tertinggal (Kuadran IV). Pada indikator yaitu laju pertumbuhan ekonomi (LPE) dan pendapatan (PDRB) per kapita. Kuadran II yaitu wilayah maju tapi tertekan tidak terdapat WP yang masuk kategori tersebut. Purwasuka merupakan WP dengan rata-rata PDRB per kapita tertinggi se-Jawa Barat dengan nilai Rp. 39,387,000,-. Peringkat kedua diduduki oleh WP KK Cekungan Bandung dan Bodebekpunjur dengan nilai Rp. 32,136,000,- dan 30,179,000,-. Hal ini semakin mempertegas dominasi ketiga WP tersebut dalam kontribusinya terhadap PDRB Jawa Barat.

WP dengan rata-rata PDRB perkapita terendah terdapat pada WP PriatimPangandaran yaitu sebesar Rp. 15,165,000,-. Fakta tersebut menunjukkan perekonomian masih belum berkembang pesat dan belum banyak pergeseran struktur perekonomian. WP dengan rata-rata LPE tertinggi diraih oleh WP KK Cekungan Bandung dan Bodebekpunjur dengan nilai $6.14 \%$ dan $6.07 \%$. Letak strategis dekat pusat pemerintahan merupakan faktor pendorong pertumbuhan ekonomi tinggi. Rata-rata LPE terendah berada pada WP Ciayumajakuning sebesar $5.12 \%$. Hal ini menunjukkan WP Ciayumajakuning sebagai daerah relatif tertinggal dengan ratarata PDRB perkapita dan rata-rata LPE di bawah nilai Jawa Barat.

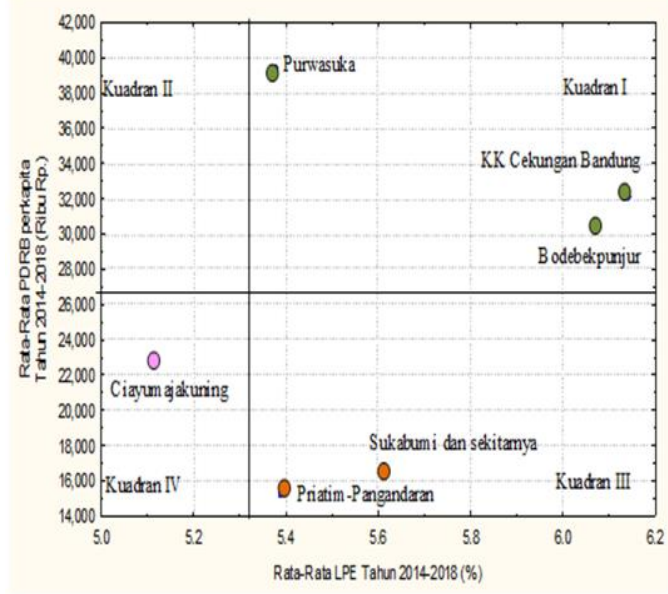

Gambar 4. Tipologi Klassen antar WP Jawa Barat

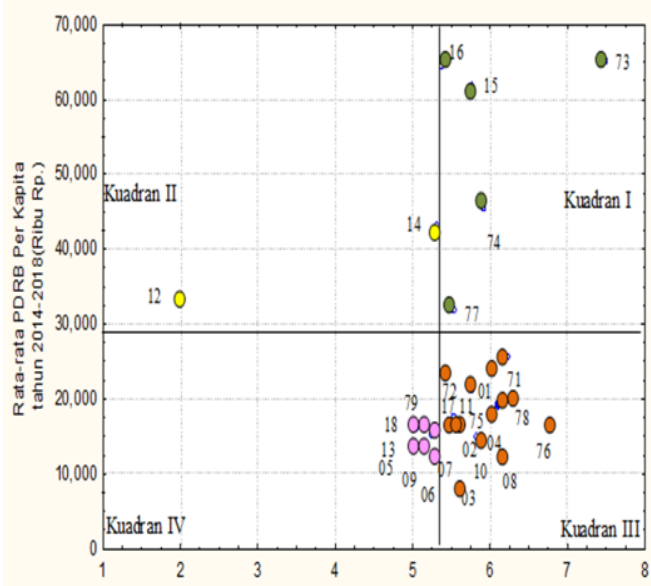

Gambar 5. Tipologi Klassen kabupaten/kota dalam WP Jawa Barat 
Tipologi klassen antar kabupaten/ kota dalam WP Jawa Barat terdapat pada Gambar 5. Kabupaten/kota Jawa Barat sebagian besar berada pada kuadran III tipologi klassen. Terdapat 14 kabupaten/kota dalam kuadran III. Hal ini menunjukkan kabupaten/kota dengan kategori berkembang cepat mendominasi wilayah Jawa Barat. Pada kuadran IV terdapat enam kabupaten/kota yang berkategori wilayah relatif tertinggal. Pada wilayah ini pembangunan perlu ditingkatkan untuk mendorong LPE dan PDRB per kapita. Wilayah cepat maju dan tumbuh (kuadran I) beranggotakan lima kabupaten/kota yang diharapkan hasil pembangunan dan ekonominya memberikan efek menyebar pada wilayah sekitarnya. Kategori wilayah maju tapi tertekan (kuadran II) merupakan kuadran dengan anggota terkecil yaitu dua kabupaten. Tipologi klassen kabupaten/kota dalam WP Jawa Barat secara spasial ditampilkan pada Gambar 6.

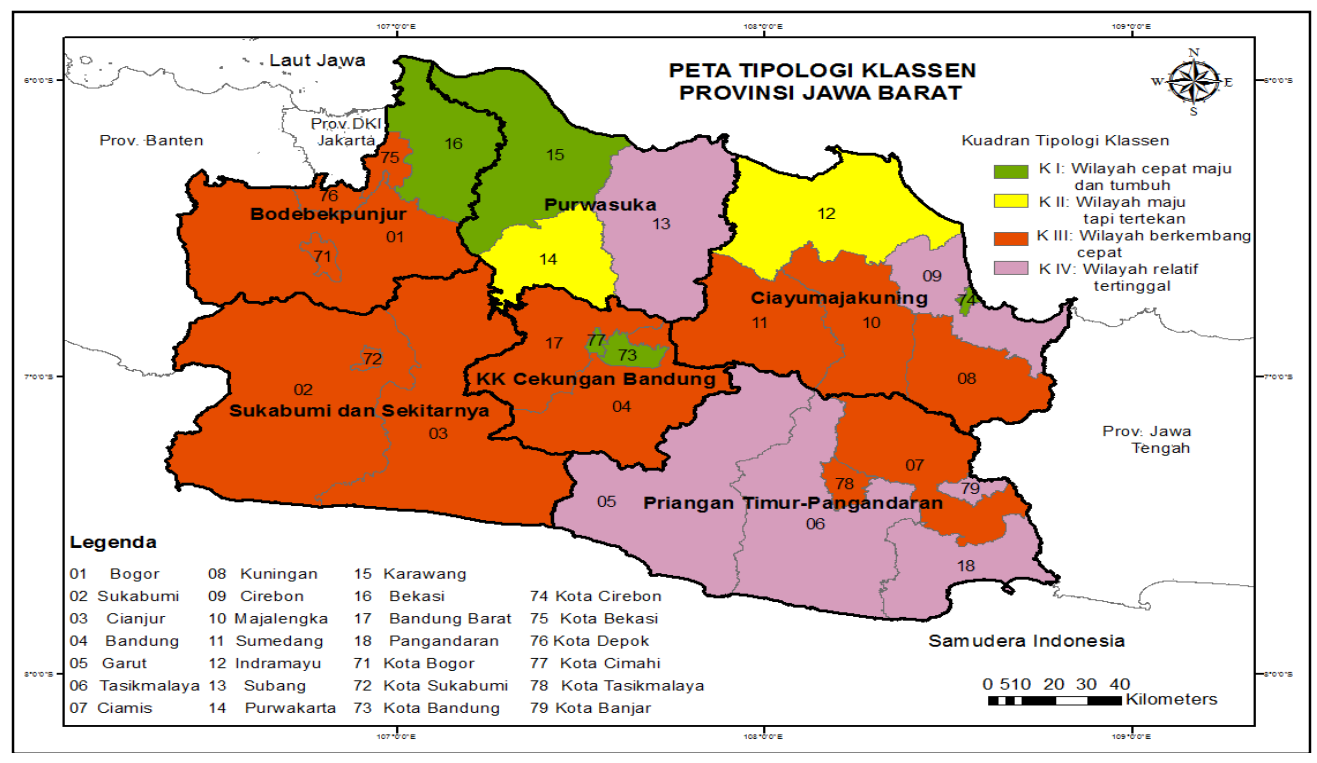

Gambar 6. Peta tipologi klassen kabupaten/kota dalam WP Jawa Barat

Daerah yang relatif tertinggal berdasarkan Gambar 18 sebagian besar berada di wilayah sebelah timur Jawa Barat. WP Priangan Timur-Pangandaran merupakan WP yang didominasi kabupaten/kota dengan kategori kuadran IV. Wilayah Jawa Barat bagian tengah dan barat mempunyai kondisi yang lebih baik dengan dominasi kuadran III dan I dibanding wilayah bagian timur. Hal ini disebabkan wilayah bagian barat dan tengah merupakan pusat pertumbuhan dan pemerintahan. Lokasi yang strategis dengan jarak yang tidak terlalu jauh dari ibukota negara dan provinsi membuat wilayah tersebut berkembang pesat dibandingkan bagian timur Jawa Barat.

Kota Bandung, Kota Cimahi, Bekasi, dan Karawang merupakan wilayah yang berada pada kuadran I pada WP KK
Cekungan Bandung, Bodebekpunjur dan Purwasuka. Posisi kabupaten/kota tersebut masih tetap bila dibandingkan dengan penelitian Pravitasari (2009). Hal ini mengindikasikan stabilitas dan kontinuitas pembangunan khususnya bidang ekonomi Kota Cirebon pada WP Ciayumajakuning merupakan wilayah cepat maju dan tumbuh yang mengalami pergeseran dari kuadran II Tahun 2000-2007 pada penelitian Pravitasari (2009) menjadi kuadran I pada penelitian ini. Aktivitas perekonomian Kota Cirebon sebagai kota inti WP Ciayumajakuning mengalami kemajuan yang merangsang wilayah sekitarnya. Indikasi Kota Cirebon sebagai growth pole yaitu hampir 55\% kawasan merupakan lahan terbangun (Lestari et al. 2017). 
Tabel 2 Persentase kabupaten/kota dalam kuadran tiap WP

\begin{tabular}{lcccccccc}
\hline \multirow{2}{*}{ WP } & \multicolumn{8}{c}{ Jumlah dan persentase kabupaten/kota terhadap Jawa Barat } \\
\cline { 2 - 10 } & K I & $\%$ & K II & $\%$ & K III & $\%$ & K IV & $\%$ \\
\hline Bodebekpjr & 1 & 3.70 & - & - & 4 & 14.81 & - & - \\
Purwasuka & 1 & 3.70 & 1 & 3.70 & - & - & 1 & 3.70 \\
Ciayumajakng & 1 & 3.70 & 1 & 3.70 & 3 & 11.11 & 1 & 3.70 \\
Priatim-Pngndrn & - & - & - & - & 2 & 7.41 & 4 & 14.81 \\
KK Cek Bdg & 2 & 7.41 & - & - & 2 & 7.41 & - & - \\
Sukabumi dsk & - & - & - & - & 3 & 11.11 & - & - \\
\hline Jawa Barat & 5 & 18.52 & 2 & 7.41 & 14 & 51.85 & 6 & 22.22 \\
\hline
\end{tabular}

Sumber: Hasil Penelitian, 2019

Tabel 2 menunjukkan banyak dan besarnya persentase kabupaten/kota dalam WP di Jawa Barat. WP KK Cekungan Bandung mempunyai persentase kabupaten/kota terbesar pada kuadran I (7.41\%). Kuadran III persentase tertinggi berada pada WP Bodebekpunjur (14.81\%). WP dengan penyumbang kuadran IV terbanyak yaitu Priatim-Pangandaran (14.81\%). Kabupaten/kota dalam kuadran IV ada 6, jumlah ini menurun drastis bila dibandingkan penelitian Pravitasari (2009) yang berjumlah 14 kabupaten/kota. Hal ini diikuti dengan sepuluh kabupaten/kota yang bergeser dari kuadran IV pada penelitian sebelumnya menjadi kuadran III pada penelitian ini. Kenyataan ini memperlihatkan kemajuan sektor perekonomian Jawa Barat dalam kurun waktu sepuluh tahun. Indikatornya yaitu PDRB per kapita dan LPE berkembang pesat sehingga daerah tertinggal bergeser menjadi daerah berkembang cepat.

\section{Pengelompokan Karakteristik Wilayah}

Pengelompokan wilayah bertujuan untuk mengelompokkan wilayah yang punya kesamaan atau kemiripan berdasarkan karakteristik tertentu. Analisis untuk mengelompokkan wilayah yaitu analisis gerombol (cluster analysis). Penelitian ini menggunakan delapan karakteristik yaitu persentase lahan sawah, terbangun, hutan, rata-rata LPE tahun 2014-2018, rata-rata kepadatan penduduk tahun 2014-2018, ratarata pertumbuhan penduduk tahun 2014-2018, rata-rata PDRB per kapita tahun 2014-2018,
Indeks Perkembangan Wilayah (IPW) tahun 2018.

Hasil analisis gerombol WP Jawa Barat dengan metode berhirarki (joining/tree clustering) menghasilkan dendogram sebagaimana terlihat pada Gambar 7 . Penentuan jumlah gerombol dilakukan dengan melakukan pemotongan pada garis terpanjang dari dendogram yang terbentuk. Pemotongan garis dilakukan pada jarak 5.5 yang terbentuk dari garis terpanjang (garis yang terbentuk dari gabungan WP Bodebekpunjur dan KK Cekungan Bandung. Berdasarkan dendogram Gambar 7 WP jawa Barat terbagi dalam dua kelompok/tipologi.

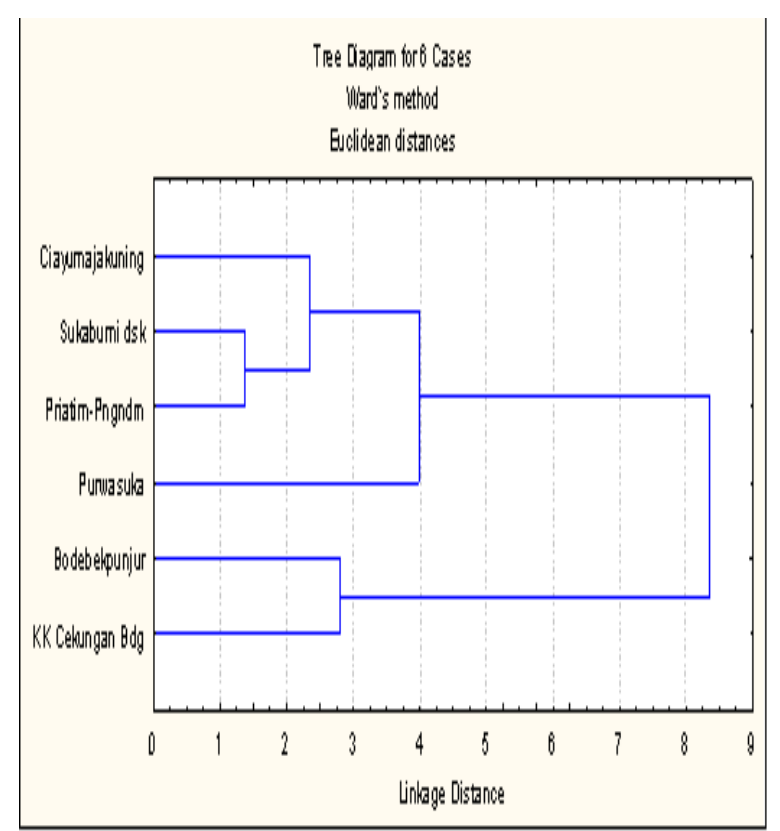

Gambar 7. Dendogram WP Jawa Barat dengan analisis gerombol berhirarki 
Pada tipologi/cluster I terdiri dari tiga anggota yaitu WP Ciayumajakuning, Sukabumi dsk serta Purwasuka. Tipologi/cluster II beranggotakan dua WP yaitu Bodebekpunjur dan KK Cekungan Bandung. Hal ini berarti WP Bodebekpunjur dan KK Cekungan Bandung mempunyai karakteristik yang relatif sama atau lebih mirip dibanding WP lain. Kekonsistenan hasil analisis gerombol/klaster dengan metode berhierarki bisa diuji dengan melihat hasil analisis gerombol metode tidak berhirarki (K-means clustering). Caranya yaitu dengan mengklasifikasi nilai mean masing-masing variabel penciri tiap gerombol/klaster.

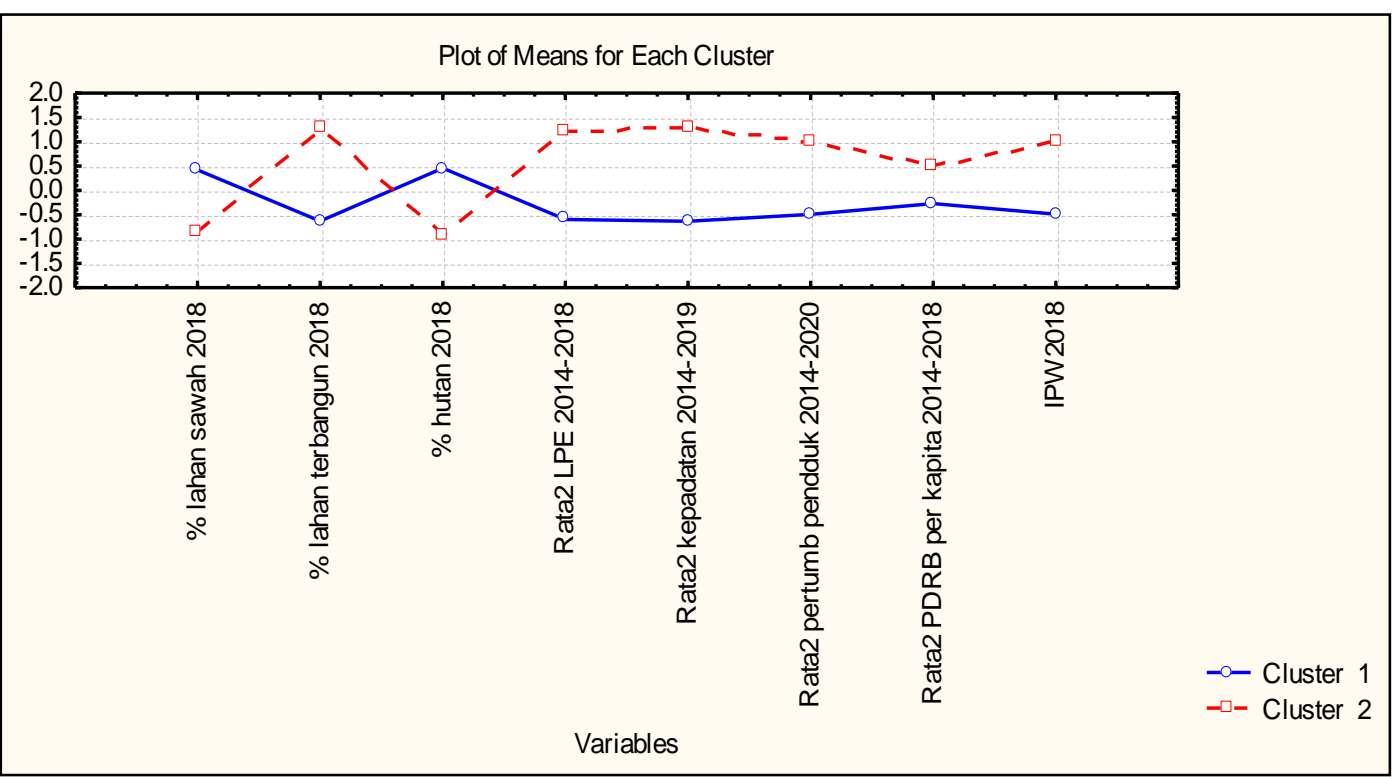

Gambar 8. Grafik WP Jawa Barat dengan analisis gerombol tidak berhirarki

Gambar 8 menunjukkan hasil metode ini sama seperti metode berhirarki pengelompokan WP dengan analisis cluster (konsisten). Kelompok/tipologi WP metode tidak berhirarki. Terdapat dua mempunyai karakteristik sebagaimana kelompok / tipologi WP berdasarkan terdapat pada Tabel 3.

Tabel 3. Karakteristik tipologi/kelompok WP Jawa Barat

\begin{tabular}{|c|c|c|c|c|c|c|c|c|}
\hline \multirow[b]{2}{*}{ Cluster } & \multirow[b]{2}{*}{ WP } & \multicolumn{7}{|c|}{ Karakteristik/Variabel } \\
\hline & & \%sawah & $\begin{array}{c}\text { \%terba- } \\
\text { ngun }\end{array}$ & LPE & $\begin{array}{l}\text { Kepa- } \\
\text { datan } \\
\text { pendu- } \\
\text { duk }\end{array}$ & $\begin{array}{l}\text { Pertum- } \\
\text { buhan } \\
\text { pendu- } \\
\text { duk }\end{array}$ & $\begin{array}{l}\text { PDRB } \\
\text { per } \\
\text { kapita }\end{array}$ & IPW \\
\hline 1 & $\begin{array}{l}\text { Ciayumajakng, } \\
\text { Sukabumi dsk, } \\
\text { Priatim-Pngndrn, } \\
\text { Purwasuka }\end{array}$ & tinggi & rendah & rendah & rendah & rendah & rendah & rendah \\
\hline 2 & $\begin{array}{l}\text { Bodebekpjr, KK } \\
\text { Cek Bdg }\end{array}$ & rendah & tinggi rendah & tinggi & tinggi & tinggi & tinggi & tinggi \\
\hline
\end{tabular}

Sumber: Hasil Penelitian, 2019

Dominasi cluster dua yang beranggotakan WP Bodebekpunjur dan KK Cekungan Bandung terlihat pada Gambar 8. Terdapat 6 karakteristik yang berkategori tinggi berbanding 2 pada tipologi 1 .
Persentase lahan terbangun yang tinggi dibandingkan persentase sawah dan hutan yang rendah menunjukkan sektor perekonomian didominasi sektor sekunder dan tersier. Kepadatan dan pertumbuhan 
penduduk yang tinggi merupakan ciri tipologi dua merupakan growth pole dan aktivitas ekonomi di Jawa Barat. Hal tersebut mendorong tingginya pendapatan perkapita dibanding tipologi satu. IPW membuktikan tipologi dua memiliki perkembangan wilayah lebih maju dibanding tipologi satu.

Tipologi 1 mempunyai karakteristik berkategori rendah lebih banyak yaitu 6 dibanding 2 pada tipologi 2. Tipologi ini memiliki karakteristik persentase swah dan hutan yang tinggi. Hal ini menunjukkan sektor perekonomian masih didominasi sektor primer. LPE dan PDRB per kapita berkategori rendah berarti wilayah tipologi rendah disebabkan banyak penduduk yang berpindah ke kota puntuk bekerja. Kenyataan ini sesuai dengan Penelitian Hamri et al. (2016) membuktikan bahwa salah satu penyebab migrasi yaitu upah yang lebih tinggi dan prospek pekerjaan yang lebih baik di daerah perkotaan. Pendapatan dan pekerjaan memikat orang ke pusat pertumbuhan disebabkan manfaat yang dirasakan lebih besar di pusat-pusat pertumbuhan. IPW yang rendah berarti tipologi satu perkembangan wilayah berdasarkan fasilitas dan prasarana masih tertinggal.

\section{Tingkat Perkembangan Wilayah}

Salah satu indikator perkembangan wilayah yaitu tersedianya fasilitas yang memadai dan bisa dimanfaatkan oleh seluruh lapisan masyarakat. Prioritas pembangunan juga diarahkan untuk mengoptimalkan pemanfaatan sarana pelayanan dan meningkatkan pemerataan jangkauan pelayanan tersebut bagi seluruh lokasi wilayah. Metode untuk mengetahui perkembangan wilayah yaitu analisis skalogram. Analisis ini menghasilkan hirarki atau urutan peringkat wilayah berdasarkan jenis dan jumlah unit prasarana pembangunan.

Penelitian ini menggunakan empat variable pada analisiss skalogram yaitu fasilitas pendidikan, kesehatan, ekonomi, dan sosial. Fasilitas-fasilitas tersebut menunjukkan adanya differentiation dan centrality wilayah. Semakin banyak dan beragam jenis fasilitas yang dimiliki wilayah maka semakin berpotensi menjadi pusat pertumbuhan. Tingkat perkembangan wilayah Jawa Barat dianalisis pada tiga titik tahun yaitu 2011, 2014, dan 2018 sehingga bisa diketahui laju hirarki wilayahnya. Hasil skalogram berbobot antar WP di Jawa Barat terdapat pada Tabel 4.

Tabel 4 Perkembangan WP Jawa Barat tahun 2011, 2014 dan 2018

\begin{tabular}{|c|c|c|c|c|c|c|c|c|c|}
\hline \multirow[b]{2}{*}{ WP } & \multicolumn{3}{|c|}{2011} & \multicolumn{3}{|c|}{2014} & \multicolumn{3}{|c|}{2018} \\
\hline & IPW & $\begin{array}{c}\text { Jum- } \\
\text { lah } \\
\text { Jenis } \\
\text { Fasi- } \\
\text { litas }\end{array}$ & Hirarki & IPW & $\begin{array}{l}\text { Jum- } \\
\text { lah } \\
\text { Jenis } \\
\text { Fasi- } \\
\text { litas }\end{array}$ & Hirarki & IPW & $\begin{array}{l}\text { Jum- } \\
\text { lah } \\
\text { Jenis } \\
\text { Fasi- } \\
\text { litas }\end{array}$ & Hirarki \\
\hline Bodebekpjr & 52.76 & 23 & Hirarki 1 & 51.40 & 23 & Hirarki 1 & 52.43 & 23 & Hirarki 1 \\
\hline Purwasuka & 4.38 & 12 & Hirarki 3 & 2.64 & 9 & Hirarki 3 & 3.15 & 12 & Hirarki 3 \\
\hline Ciayumajakng & 25.44 & 22 & Hirarki 2 & 23.57 & 23 & Hirarki 3 & 22.38 & 22 & Hirarki 3 \\
\hline Priatim-Pngndrn & 25.83 & 18 & Hirarki 2 & 26.43 & 19 & Hirarki 2 & 27.84 & 18 & Hirarki 2 \\
\hline KK Cek Bdg & 32.41 & 23 & Hirarki 2 & 29.36 & 23 & Hirarki 2 & 29.46 & 22 & Hirarki 2 \\
\hline Sukabumi dsk & 10.93 & 15 & Hirarki 3 & 10.96 & 17 & Hirarki 3 & 11.13 & 17 & Hirarki 3 \\
\hline
\end{tabular}

Sumber: Hasil Penelitian, 2019

Tingkat perkembangan wilayah antar WP Jawa Barat pada Tabel 20 menunjukkan adanya peningkatan dan penurunan (IPW dan hirarki) dalam tiga titik tahun. Bodebekpunjur merupakan WP yang konsisten menduduki hirarki/tingkat perkembangan wilayah tertinggi. Indeks Perkembangan Wilayah (IPW) WP Bodebekpunjur selalu lebih tinggi dibanding WP lainnya. Hal ini menunjukkan dominasi 
kelengkapan sarana dan prasarana yang tersedia. WP yang konsisten di hirarki dua adalah KK Cekungan Bandung dan PriatimPangandaran. WP KK Cekungan Bandung mempunyai jenis fasilitas yang sama dengan Bodebekpunjur yaitu 22-23 namun dengan jumlah fasilitas yang lebih sedikit sehingga berada pada hirarki kedua.

WP Purwasuka serta Sukabumi dan sekitarnya konsisten di hirarki tiga selama tiga titik waktu. IPW kecil serta jumlah dan jenis fasilitas yang sedikit membuat dua WP tersebut berada pada hirarki terendah. Kenyataan ini menunjukkan tingkat perkembangan kedua WP masih jauh tertinggal dari segi fasilitas dan sarana pelayanan. Ciayumajakuning merupakan WP yang mengalami penurunan hirarki perkembangan wilayah. Pada tahun 2011 dan 2014 WP Ciayumajakuning masih menduduki hirarki 2 namun menurun menjadi hirarki 3 pada tahun 2018. Artinya WP ini mengalami penurunan jumlah fasilitas namun dengan jenis fasilitas yang relatif sama jumlahnya (22-23 fasilitas). Grafik IPW antar WP Jawa Barat terdapat pada Gambar 9.
Secara umum IPW antar WP Jawa Barat relatif stabil berdasarkan Gambar 9. Tidak terdapat laju kenaikan atau penurunan IPW yang cukup mencolok. IPW Bodebekpunjur berada jauh di atas WP lainnya, hal ini memperlihatkan lengkap dan beragamnya fasilitas dengan jumlah yang relatif merata di setiap wilayah. Posisi yang strategis dekat pusat pemerintahan dan perekonomian mendorong pertumbuhan sarana dan prasarana penunjang. WP Sukabumi dsk serta PriatimPangandaran memiliki laju kenaikan IPW dalam tiga titik tahun. Penambahan jumlah dan jenis fasilitas mendorong laju kenaikan IPW. Ciayumajakuning memiliki IPW yang terus menurun, hal ini dipengaruhi berkurangnya jenis dan jumlah fasilitas yang ada. WP Bodebekpunjur, Purwasuka, dan KK Cekungan Bandung memiliki penurunan IPW pada tahun 2014. Penurunan jumlah dan jenis fasilitas sebagai pendorong turunnya IPW tersebut disebabkan tutup atau tidak aktifnya fasilitas tertentu.

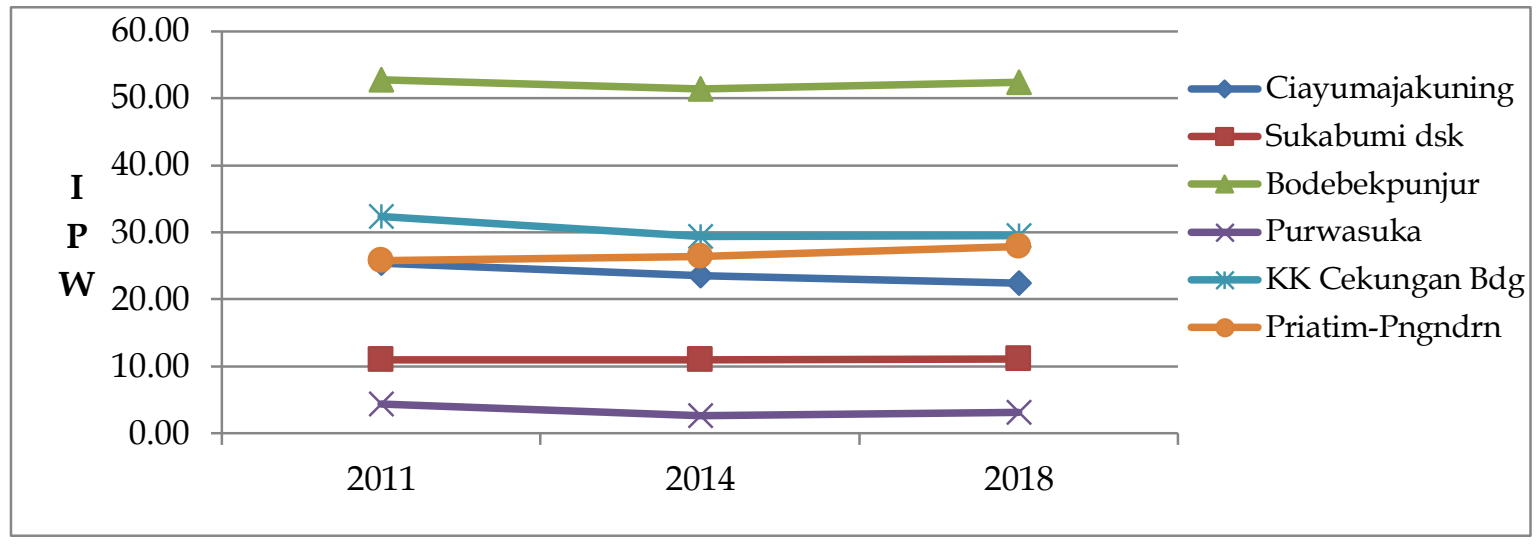

Gambar 9 Grafik IPW pada WP Jawa Barat Tahun 2011, 2014 dan 2018

Hirarki wilayah dari titik awal pengamatan (2011) sampai titik akhir (2018) bisa menggambarkan laju perkembangan wilayah. Kategori hirarki tersebut mencerminkan capaian perkembangan wilayah selama delapan tahun dari segi sarana dan prasarana. Informasi tersebut diharapkan menjadi dasar evaluasi pemerintah dalam menyusun kebijakan pembangunan. Alur pergeseran hirarki kabupaten/kota dalam WP Jawa Barat seperti yang dilakukan Priadi (2018) terdapat pada Tabel 5. 
Tabel 5. Klasifikasi kabupaten/kota Jawa Barat berdasarkan pergeseran tingkat perkembangan wilayah dari tahun 2011 sampai 2018

\begin{tabular}{clcc}
\hline No & Kategori (pergeseran hirarki) & $\begin{array}{c}\text { Jml } \\
\text { kabupaten/kota }\end{array}$ & Persentase (\%) \\
\hline 1 & Baik-Baik (I-I) & 2 & 7.41 \\
2 & Sedang-Baik (II-I) & 1 & 3.70 \\
3 & Rendah-Baik (III-I) & 0 & 0.00 \\
4 & Baik-Sedang (I-II) & 1 & 3.70 \\
5 & Sedang-Sedang (II-II) & 6 & 22.22 \\
6 & Rendah-Sedang (III-II) & 1 & 3.70 \\
7 & Baik-Rendah (I-III) & 0 & 0.00 \\
8 & Sedang-Rendah (II-III) & 1 & 3.70 \\
9 & Rendah-Rendah (III-III) & 15 & 55.56 \\
\hline Jumlah & & 27 & 100.00 \\
\hline
\end{tabular}

Sumber: Hasil Penelitian, 2019

Pergeseran hirarki perkembangan wilayah berdasarkan Tabel 5 menunjukkan sebagian besar $(55.56 \%)$ berada pada kategori rendah-rendah. Hal ini berarti separuh lebih wilayah Jawa Barat masih rendah tingkat perkembangan wilayahnya. Terdapat 15 kabupaten/kota yang masih konsisten di hirarki III dan belum berhasil bergeser. Kategori dengan persentase terbesar kedua yaitu sedang-sedang $(22.22 \%)$, artinya belum ada peningkatan perkembangan wilayah. Penurunan hirarki wilayah terdapat pada kategori baik-sedang dan sedang-rendah dengan persentase masing-masing $\quad 3.70 \%$. Peningkatan perkembangan wilayah dengan kategori sedang-baik masih relatif kecil (3.70\%) dan kategori stabil baik-baik berada pada besaran $7.41 \%$. Kenyataan ini membuktikan perlunya peningkatan jumlah dan jenis fasilitas dengan sebaran yang merata dan mudah diakses. Pergeseran hirarki wilayah secara jelas terdapat pada Gambar 10.

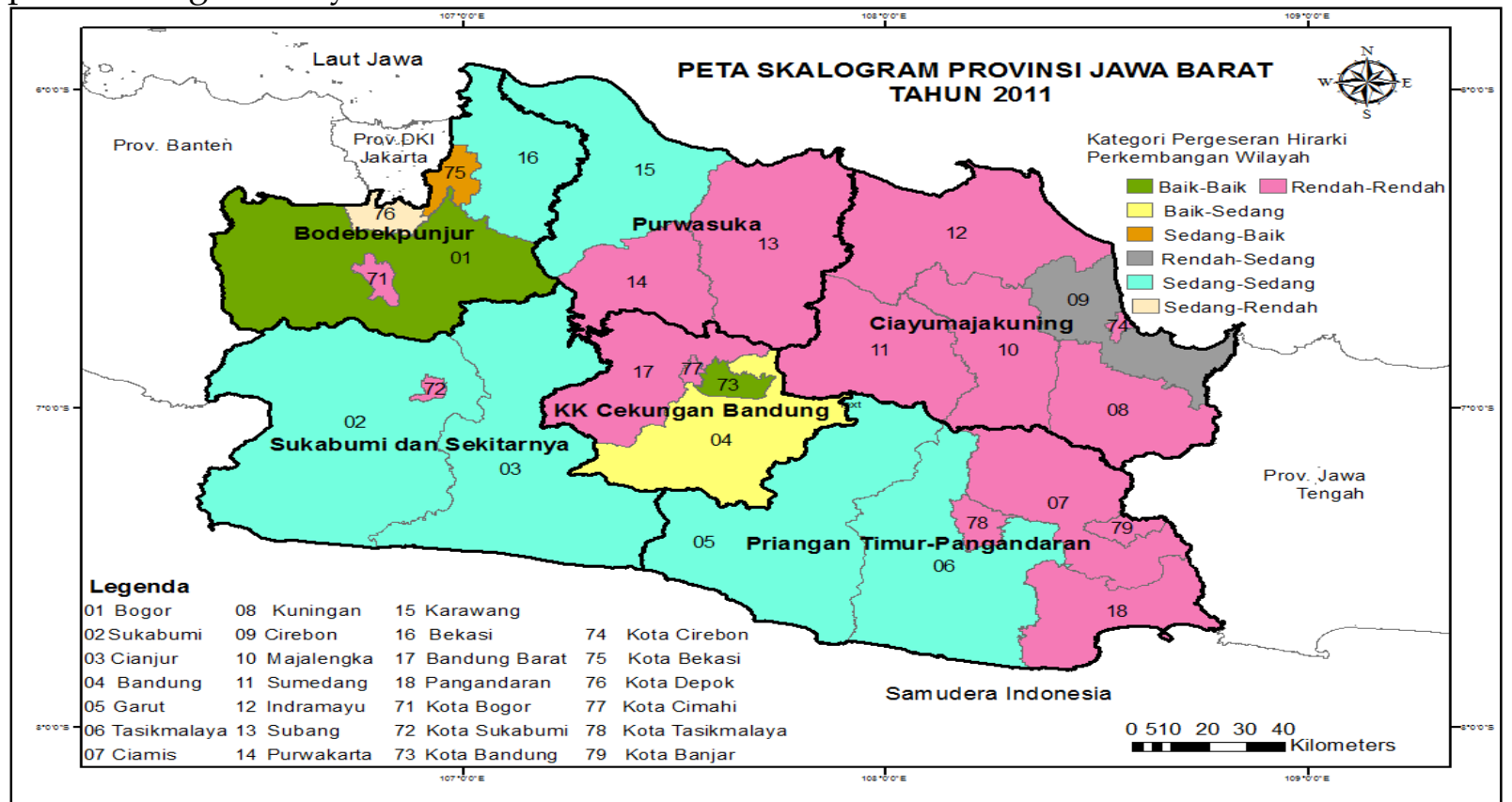

Gambar 10. Peta pergeseran hirarki skalogram kabupaten/kota dalam WP Jawa Barat 
Tingkat perkembangan wilayah kategori rendah-rendah terdapat pada Sebagian besar WP Ciayumajakuning, Priatim-Pangandaran, KK Cekungan Bandung. WP Bodebekpunjur (Kota Bogor) dan Sukabumi dan sekitarnya (Kota Sukabumi) juga berkategori pergeseran hirarki rendah-rendah. Hal ini menunjukkan wilayah tersebut cukup sulit untuk berkembang (stagnan). Jumlah dan jenis fasilitas cukup sedikit penambahannya sehingga belum melampaui rata-rata Jawa Barat. Kategori sedang-sedang berada di bagian pantai selatan Jawa Barat dan bagian kecil pesisir utara. Perkembangan wilayah tersebut cenderung stabil namun belum bisa berkembang pesat. Kabupaten Cirebon menjadi satu-satunya anggota WP Ciayumajakuning yang berhasil keluar dari perkembangan wilayah rendah ke sedang. Kota Bekasi juga berhasil meningkatkan perkembangan wilayah dari sedang ke baik. Kabupaten Bekasi dan Kota Bandung merupakan wilayah yang konsisten berada pada hirarki I dalam kurun waktu delapan tahun. Fakta ini memperlihatkan kedua kota tersebut merupakan pusat pertumbuhan yang memberikan pelayanan pada wilayah sekitarnya. Jenis dan jumlah fasilitas yang terus bertambah menjadikan kota ini tujuan wilayah lain untuk mendapatkan fasilitas yang terbaik. Perkembangan wilayah Jawa Barat tidak terdapat kategori baik-rendah dan rendahbaik artinya tidak ada peningkatan atau penurunan hirarki yang sangat drastis.

\section{Arahan Rencana dan Strategi Pembangunan Wilayah Jawa Barat \\ Berdasarkan analisis tipologi} klassen, analisis gerombol, dan analisis skalogram dapat dibuat rangkuman perkembangan wilayah Jawa Barat. Prioritas pembangunan wilayah dilakukan dengan merujuk pada penelitian Marzuki (2018) yang meneliti prioritas pengembangan wilayah Kabupaten Cirebon. Prioritas pembangunan WP Jawa Barat terdapat dalam Tabel 6.
Tabel 6. Prioritas pembangunan WP Jawa Barat

\begin{tabular}{|c|c|c|c|c|}
\hline WP & $\begin{array}{l}\text { Kuadran } \\
\text { perkem- } \\
\text { bangan } \\
\text { pereko- } \\
\text { nomian }\end{array}$ & $\begin{array}{l}\text { Tingkat } \\
\text { perkemba } \\
\text { ngan } \\
\text { wilayah }\end{array}$ & $\begin{array}{l}\text { Tipologi } \\
\text { / kelom- } \\
\text { pok } \\
\text { wilayah }\end{array}$ & $\begin{array}{c}\text { Priori- } \\
\text { tas } \\
\text { pem- } \\
\text { bangu } \\
\text { nan }\end{array}$ \\
\hline $\begin{array}{c}\text { Ciayumaja } \\
\text { kng }\end{array}$ & IV & Hirarki 3 & Tipologi I & 1 \\
\hline Sukabumi ds & III & Hirarki 3 & Tipologi I & 2 \\
\hline $\begin{array}{l}\text { Priatim- } \\
\text { Pngndrn }\end{array}$ & III & Hirarki 2 & Tipologi I & 3 \\
\hline Purwasuka & I & Hirarki 3 & Tipologi I & 4 \\
\hline $\begin{array}{c}\text { KK Cek } \\
\text { Bdg }\end{array}$ & I & Hirarki 2 & Tipologi II & 5 \\
\hline Bodebekpjr & I & Hirarki 1 & Tipologi II & 6 \\
\hline
\end{tabular}

Sumber: Hasil Penelitian, 2019

WP Ciayumajakuning merupakan WP yang memerlukan prioritas pertama pembangunan. Hal ini terlihat dari tipologi perkembangan daerah yang masuk kuadran IV (daerah relatif tertinggal). Strategi pembangunan wilayah dilakukan dengan peningkatan fasilitas dan aktivitas perekonomian. WP Sukabumi dsk serta Priatim-Pangandaran merupakan prioritas pembangunan kedua dan ketiga. Peningkatan aktivitas ekonomi dan fasilitas di wilayah belakang (hinterland) diperlukan untuk meningkatkan perkembangan wilayah. WP Purwasuka menjadi prioritas pembangunan keempat. Sektor sekunder dan tersier sudah berkembang namun perlu diiringi dengan peningkatan fasilitas penunjangnya. KK Cekungan Bandung dan Bodebekpunjur menjadi WP dengan prioritas pembangunan kelima dan keenam. WP tersebut masuk dalam tipologi yang sama (tipologi II) artinya karakteristik wilayahnya memiliki kesamaan. Posisi strategis dekat pusat pemerintahan membuat tingkat perekonomian berkembang pesat. WP KK Cekungan Bandung menempati hirarki 2 perkembangan wilayah sehingga memerlukan penambahan fasilitas pelayanan. WP Bodebekpunjur merupakan WP termaju dengan tingkat perkembangan wilayah yang tinggi. Wilayah tersebut merupakan pusat perekonomian yang menjadi tujuan urbanisasi penduduk. Pembangunan WP ini perlu 
mempertimbangkan aspek kapasitas wilayah dan pelestarian lingkungan.

\section{KESIMPULAN}

Perkembangan wilayah Jawa Barat masih terkonsentrasi di WP Bodebekpunjur dan KK Cekungan Bandung yang memiliki posisi strategis dekat dengan pusat pemerintahan. Aktivitas perekonomian yang tinggi serta fasilitas lengkap dan beragam menjadikan dua WP tersebut menjadi wilayah maju. WP Ciayumajakuning merupakan WP dengan tingkat perkembangan wilayah terendah yang memerlukan percepatan pembangunan. WP Priatim-Pangandaran serta Sukabumi dan sekitarnya merupakan WP dengan perkembangan wilayah sedang. Purwasuka termasuk WP yang mempunyai aktivitas ekonomi tinggi namun persebaran fasilitas belum merata. Secara umum strategi untuk memeratakan pembangunan yaitu dengan meningkatkan perkembangan wilayah daerah belakang (hinterland) pada tiap WP. Pusat-pusat pertumbuhan baru tersebut diharapkan dapat mendorong laju pertumbuhan ekonomi. Wacana pemindahan ibukota Jawa Barat dari Kota Bandung ke beberapa daerah alternative Bandung, Bandung Barat, Cirebon-SubangMajalengka merupakan salah satu upaya untuk memeratakan pembangunan.

\section{UCAPAN TERIMA KASIH}

Penulis mengucapkan terima kasih kepada BPS Provinsi Jawa Barat dan BPS Kota Sukabumi yang telah memberikan kemudahan akses data untuk menunjang penelitian ini. Ucapan terima kasih juga penulis sampaikan kepada Pusbindiklatren Bappenas yang telah mendanai penelitian.

\section{DAFTAR PUSTAKA}

Akrofi M.M., Akanbang B.A.A, Abdallah C. K. (2018). Dimensions of Regional Inequalities in Ghana: Assessing Disparities in the Distribution of Basic Infrastructure among Northern and Southern Districts. International Journal of Regional Development, 5(1), 25-43.
Aprianoor P., Muktiali M. (2015). Kajian Ketimpangan Wilayah di Provinsi Jawa Barat. Jurnal Teknik PWK, 4(4), 484-498.

[BPS] Badan Pusat Statistik Provinsi Jawa Barat. (2017). Sensus Ekonomi 2016 Analisis Hasil Listing Potensi Ekonomi Jawa Barat. Badan Pusat Statistik, Bandung.

Baga, CM.A. (2015). Dinamika Perkembangan Kota Kecil dan FaktorFaktor yang Mempengaruhinya (Studi Kasus pada Kecamatan Muntilan, Mungkid, dan Salam). Jurnal Pembangunan Wilayah dan Kota, 11(3), 287-298.

Fafurida. (2012). Analysis of Inter Sectoral Linkages in Semarang Regency. Economic Journal of Emerging Markets, 4(1):15-24.

Hamri, E., Putri, E.I., Siregar, H.J. dan Bratakusumah, DS. (2016). Kebijakan Pemekaran Wilayah dan Pengembangan Pusat Pertumbuhan Ekonomi Kota Tasikmalaya. Jurnal Ekonomi dan Kebijakan Publik, 7(1), 111125.

Latuconsina, ZM.Y. (2017). Model Pembangunan Kabupaten Malang Provinsi Jawa Timur Berbasis Sistem Wilayah Pengembangan. Tesis Sekolah Pascasarjana Institut Pertanian Bogor. Bogor. $125 \mathrm{hlm}$.

Lestari, R.A., Fatimah, E. dan Barus, L.S. (2017). Identifikasi Perkembangan Perkotaaan Metropolitan Cirebon Raya. Seminar Nasional Cendekiawan, 3(2), 199-205.

Marzuki, A. (2018). Analisis Tingkat Perkembangan Wilayah, Konversi Lahan Dan Rasio Tanah Terdaftar Serta Arahan Pengembangan Wilayah Di Kabupaten Cirebon. Tesis Sekolah Pascasarjana Institut Pertanian Bogor. Bogor. 140 hlm.

McGarigal K., Plunkett E.B., Willey L.L., Compton B.W., DeLuca W.V. and Grand J. (2018). Modeling NonStationary Urban Growth: The SPRAWL Model And The Ecological 
Impacts of Development. Landscape and Urban Planning, 177(18), 178-190

Muta'ali, L. (2015). Teknik Analisis Regional untuk Perencanaan Wilayah, Tata Ruang dan Lingkungan. Badan Penerbit Fakultas Geografi UGM, Yogyakarta.

Panuju DR, Rustiadi E. 2013. Teknik Analisis Perencanaan Pengembangan Wilayah. Bogor (ID): Departemen Ilmu Tanah dan Sumbedaya Lahan.

Peraturan Gubernur Jawa Barat. (2010). Rencana Tata Ruang Wilayah Provinsi Jawa Barat Tahun 2009-2029. Peraturan Daerah Nomor: 22 Tahun 2010. Gubernur Jawa Barat. Bandung.

Pratiwi, A.G., Muta'ali, L. (2018). Perkembangan Ekonomi Wilayah dan Peran Sektor Tersier di Kawasan Jakarta, Bogor, Depok, Tangerang, dan Bekasi.Jurnal Bumi Indonesia, 2(2), 1-7.

Pravitasari, A.E. (2009). Dinamika Perubahan Disparitas Regional di Pulau Jawa sebelum dan Setelah Kebijakan Otonomi Daerah. Tesis Sekolah Pascasarjana Institut Pertanian Bogor. Bogor. 179 hlm.

Prawatya NA. (2013). Perkembangan Spasial Kota-kota Kecil. Jurnal Wilayah dan Lingkungan. 1(1): 17-32.
Priadi, G. (2018). Pemerataan Sebagai Arahan Rencana Dan Strategi Pembangunan Wilayah di Kabupaten Cianjur. Tesis Sekolah Pascasarjana Institut Pertanian Bogor. Bogor. $108 \mathrm{hlm}$.

Pribadi, D.O., Rustiadi, E., Panuju, D.R., dan Pravitasari, A.E. (2017). Permodelan Perencanaan Pengembangan Wilayah. Crestpent Press, Bogor.

Rustiadi, E., Saefulhakim, S. dan Panuju, D.R. (2009). Perencanaan Pengembangan Wilayah. Crespent Press \& Yayasan Obor Indonesia, Bogor.

Sjafrizal. (1997). Pertumbuhan Ekonomi dan Ketimpangan Regional Wilayah Indonesia Bagian Barat. Yogyakarta (ID): LP3ES.

Tulenan YF, Pangemanan P, Rumagit GAJ, Tangkere EG. 2014. Perkembangan Jumlah Penduduk Dan Luas Lahan Pertanian Di Kabupaten Minahasa Selatan. Ejurnal Unsrat. 4(1):1-14.

Utari MGES. (2015). Analisis Sistem Pusat Pelayanan Permukiman di Kota Yogyakarta Tahun 2014. Journal of Economics and Policy. 8(1):62-72. 